\title{
KONSEP DIRI DAN KOMPETENSI KOMUNIKASI PENYANDANG DISABILITAS DALAM MENUMBUHKAN KEPERCAYAAN DIRI DAN AKTUALISASI DIRI DI DUNIA KEWIRAUSAHAAN KOTA MAKASSAR
}

\section{Self Concept and Communication Competence of People with Disability to Build Self Confidence and Self Actualisation in Entrepreneurship World of Makassar City}

\author{
Andi Maulana Armas ${ }^{1}$, Andi Alimuddin Unde ${ }^{2}$, Jeanny Maria Fatimah ${ }^{3}$ \\ ${ }^{1}$ Ilmu Komunikasi, Fakultas Ilmu Sosial dan Ilmu Politik, Universitas Hasanuddin, \\ (Email: maulanaarmas@gmail.com) \\ ${ }^{2}$ Ilmu Komunikasi, Fakultas Ilmu Sosial dan Ilmu Politik, Universitas Hasanuddin, \\ (Email: undealimuddin@yahoo.co.id) \\ ${ }^{3}$ Ilmu Komunikasi, Fakultas Ilmu Sosial dan Ilmu Politik, Universitas Hasanuddin \\ (Email: jeannypalinggi@ymail.com)
}

\begin{abstract}
ABSTRAK
Penyandang disabilitas memiliki keterbatasan untuk mendapatkan pekerjaan sedangkan untuk memenuhi kebutuhan hidupnya dengan berwirausaha, penyandang disabilitas harus memiliki konsep diri positif dan memiliki kompetensi komunikasi yang baik. Penelitian ini bertujuan: (1). Memahami dan mengetahui konsep diri pada penyandang disabilitas dalam menumbuhkan kepercayaan diri di dunia kewirausahaan Kota Makassar dan (2). Mengetahui kompetensi komunikasi penyandang disabilitas dalam menumbuhkan aktualisasi diri di dunia kewirausahaan Kota Makassar. Penelitian ini merupakan jenis penelitian deskriptif kualitatif. Data diperoleh melalui observasi, wawancara dan dokumentasi. Informan ditetapkan secara purposif, yaitu terdiri atas 4 orang penyandang disabilitas fisik dan 4 orang lainnya yang dianggap mengenal informan (significant others). Data dianalisis menggunakan model interaktif Miles dan Huberman. Hasil penelitian menunjukkan bahwa penyandang disabilitas yang berwirausaha memiliki konsep diri positif walaupun awalnya memiliki konsep diri negatif pada saat mengalami dan merasakan keterbatasannya yang dipengaruhi oleh persepsi dari dalam diri (in self) dan persepsi dari luar diri (out self). Penyandang disabilitas dalam berwirausaha memiliki kompetensi komunikasi yang baik yang dapat dilihat dari tiga aspek, yaitu: motivasi, pengetahuan dan keterampilan. Kompetensi komunikasi yang tidak maksimal ditemukan pada penyandang disabilitas rungu dan wicara, yaitu pada aspek pengetahuan dan keterampilan yang disebabkan oleh keterbatasan atau disabilitas yang mereka alami terhubung langsung dengan organ tubuh yang berfungsi untuk berkomunikasi.
\end{abstract}

Kata kunci : Konsep Diri, Kompetensi Komunikasi, Penyandang Disabilitas, Kewirausahaan

\begin{abstract}
Persons with disabilities have limitations to get jobs, and in order to work as entrepreneur, the disables should have a positive self-concept and have good communication competence. The research aimed at: (1). Comprehending and analysing the self-concept of the people with disability to build the self-confidence in the entrepreneurship world; (2). Analysing the communication competence of the people with disability to build the self-actualisation in the entrepreneurship world of Makassar City. This was a qualitative deskriptive research. Data were analysed using Miles and Huberman's interactive model. Data were obtained an observation, interview and documentation. Informants were determined through the purposive sampling technique consisting of 4 people with physical disability the other four were assumed to recognise the informants (significant others). The research result indicates that the people with disability who conduct their business have the positive self-concept although they intially have the negative self-concept when they undergo and feel their limitation affected by the in-self and out-self perception. In
\end{abstract}


carrying out their business, the people with disability have the good communication competence which can be viewed from three aspects: motivation, knowledge and skill. Non maximal communication competence is found in hearing and speaking disability. i.e. on the aspects of knowledge and skill cause by the limitation or disability they have are directly connected with the organs functioning to communicate.

Keywords: Self-concept, Communication competence, People with disability, Entrepreneurship.

\section{PENDAHULUAN}

Pada tahun 2015 Indonesia memiliki tantangan lebih berat lagi yaitu Masyarakat Ekonomi Asean (MEA) yang merupakan realisasi pasar bebas di Asia Tenggara. Namun, Indonesia tetap memiliki peluang besar untuk dapat mengambil manfaat dari implementasi MEA bagi kesejahteraan masyarakat Indonesia. Tujuan dibentuknya Masyarakat Ekonomi ASEAN (MEA) untuk meningkatkan stabilitas perekonomian di kawasan ASEAN, serta diharapkan mampu mengatasi masalahmasalah di bidang ekonomi antar negara ASEAN. Hal-hal tersebut tentunya dapat berakibat positif atau negatif bagi perekonomian Indonesia. Oleh karena itu dari sisi pemerintah juga dilakukan strategi dan langkah-langkah agar Indonesia siap dan dapat memanfaatkan momentum dari Masyarakat Ekonomi Asean (Suroso, 2015).

Persaingan kerja yang semakin sengit menuntut para pencari kerja untuk lebih kreatif dalam mengembangkan potensi diri. Kesempatan kerja yang tersedia tidak sebanding dengan kerja yang ada di Indonesia terlebih terlaksananya MEA (Masyarakat Ekonomi Asean), hal ini menyebabkan tingginya angka pengangguran di Indonesia. Bagi manusia normal secara fisik maupun psikis dapat bekerja sesuai dengan keinginan dan kemampuan yang dimiliki. Tapi tidak untuk penyandang disabilitas. Sama seperti manusia pada umumnya, penyandang disabilitas harus bekerja untuk memenuhi kebutuhan hidup bagi diri sendiri maupun untuk keluarganya. Namun, penyandang disabilitas memiliki berbagai keterbatasan dalam melakukan hal seperti melakukan pekerjaan.

Stigma yang tebangun di masyarakat penyandang disabilitas dianggap tidak mampu, tidak berdaya, dan perlu dibelaskasihani membuat penyandang disabilitas sulit mendapatkan pekerjaan. Perusahaan cenderung untuk menolak penyandang disabilitas ketika melamar pekerjaan dengan alasan penyandang disabilitas tidak mampu bekerja dan sulitnya akses layanan umum untuk mereka.

Sebagai warga negara Indonesia, penyandang disabilitas memiliki kedudukan, hak dan kewajiban yang sama dengan masyarakat Indonesia pada umumnya. Kesamaan hak tersebut terdapat pada filsafat Negara Pancasila dan Undang-Undang 1945. Dalam UUD 1945 pasal 27 ayat 2 "Tiap warga negara berhak atas pekerjaan dan penghidupan yang layak bagi kemanusiaan". Selain itu, Peraturan Pemerintah juga mengatur penyandang disabilitas dalam bekerja, seperti dalam Undang-Undang No. 8 Tahun 2016 Tentang Penyandang Disabilitas Pasal 53 yang mewajibkan semua instansi pemerintah, pemerintah daerah, badan usaha milik negara ataupun badan usaha milik daerah menerima $2 \%$ penyandang disabilitas dari total jumlah pegawai atau pekerja yang ada di instansi tersebut dan $1 \%$ dari total jumlah pegawai di isntansi swasta. Namun pada kenyataanyannya kuota 2\% untuk instansi pemerintah dan $1 \%$ untuk instansi swasta tidak terpenuhi dan tidak berjalan efektif.

Menurut data dari ILO (International Labour Organization) atau Organisasi Buruh Internasional (2013), pada negara berkembang termasuk Indonesia terdapat jutaan penyandang disabilitas baik perempuan dan laki-laki berada pada usia kerja, namun mayoritas tidak bekerja. Hal tersebut menunjukkan bahwa masih banyak masyarakat penyandang disabilitas kesulitan untuk memperoleh pekerjaaan baik itu pada instansi swasta maupun pemerintahan. Selain sulit mendapatkan pekerjaan, penyandang disabilitas yang akhirnya mendapatkan pekerjaan tidak jarang mendapatkan diskriminasi di tempat kerja.

Sulitnya penyandang disabilitas memperoleh pekerjaan dan seringnya mendapat diskriminasi di tempat kerja mendorong penyandang disabilitas untuk menghidupi kehidupannya dengan berwirausaha. 
Kepercayaan diri merupakan karakteristik awal yang harus dimiliki individu dalam berwirausaha. Kepercayaan diri akan timbul akibat adanya konsep diri yang baik dari setiap individu. Cara pandang penyandang disabilitas terhadap dirinya akan membentuk suatu konsep tentang diri sendiri. Konsep diri menjelaskan bagaimana individu berfikir dan merasakan tentang dirinya sendiri (Liliweri, 2015).

Selain konsep diri yang baik, penyandang disabilitas dalam berwirausaha (enterpreneur) juga harus memiliki keterampilan-keterampilan yang bisa dipergunakan di dunia kewirausahaan. Keterampilan yang dimiliki dalam dunia kewirausahaan juga harus di dukung oleh kompetensi komunikasi yang memadai, karena kompetensi komunikasi merupakan kompetensi yang sangat berpengaruh dalam meningkatkan efektivitas komunikasi. Spitzberg \& Cupach dalam Ibrahim (2002), menyatakan bahwa kompetensi komunikasi merupakan kemampuan seorang individu untuk beradaptasi dan berkomunikasi secara efektif dalam segala situasi sosial sepanjang waktu.

Pentingnya konsep diri yang baik dan kompetensi komunikasi tidak hanya bagi manusia normal tetapi juga bagi penyandang disabilitas dalam bersosialisasi dengan lingkungan sekitar dan memenuhi kebutuhan hidupnya dengan bekerja. Sehingga dalam penelitian ini difokuskan bagaimana memahami dan menganalisis konsep diri dan kompetensi yang dimiliki penyandang disabilitas dalam berwirausaha. Penelitian ini juga diharapkan dapat menjadi acuan bagi penelitian selanjutnya yang berkaitan dengan konsep diri dan kompetensi komunikasi.

\section{BAHAN DAN METODE Rancangan Penelitian}

Jenis penelitian ini adalah deskriptif kualitatif. dan menekankan pada penemuan hasil penelitian yang tidak dapat dicapai dengan menggunakan prosedur statistik atau dengan cara kuatifikasi lainnya. Hasil penelitian dipaparkan dalam bentuk naratif.

\section{Objek Penelitian}

Informan dalam penelitian ini adalah penyandang disabilitas yang terdiri dari disabilitas netra, rungu, wicara dan daksa yang memenuhi kebutuhan hidupnya dengan berwirausaha.

\section{Sumber Data dan Teknik Pengumpulan Data}

Sumber data yang digunakan dalam penelitian ini yaitu data primer dan sekunder. Data primer berupa data yang didapatkan dalam wawancara terhadap informan yang bergerak di dunia wirausaha. Data sekunder berupa data yang diperoleh dari berbagai referensi atau sumber dokumentasi, seperti buku-buku, jurnal, laporan penelitian, makalah, atau pun tulisan-tulisan yang tersebar di media online. Data ini digunakan untuk mendukung dan memperkuat hasil penelitian. Dalam penelitian ini peneliti menggunakan teknik purposive sampling yaitu teknik penentuan informan dengan pertimbangan tertentu. Pertimbangan tertentu ini misalnya orang yang dianggap paling tahu tentang apa yang peneliti harapkan (Sugiyono, 2010).

\section{Analisis Data}

Pada penelitian ini menggunakan teknik analisis data berdasarkan model Miles dan Huberman, yang menyatakan bahwa analisis data kualitatif menggunakan kata-kata yang disusun dalam sebuah teks dan kemudian dideskripsikan, dianalisis dan diinterpretasikan. Analisis data tersebut berupa Reduksi data, Display/Penyajian data dan Penarikan kesimpulan/Verifikasi.

\section{HASIL}

\section{Konsep Diri Penyandang Disabilitas}

Cara pandang individu terhadap dirinya akan membentuk suatu konsep tentang diri sendiri. Konsep tentang diri merupakan hal yang penting bagi kehidupan individu karena konsep diri menentukan bagaimana individu bertindak dalam berbagai situasi. Konsep diri juga merupakan sekumpulan keyakinan dan perasaan seseorang mengenai dirinya. Adapun konsep diri yang terbentuk dari para penyandang disabilitas dalam penelitian ini muncul karena adanya persepsi yang muncul dari dalam diri (in self) dan persepsi dari luar diri penyandang disabilitas (out self) interaksi antara penyandang disabilitas dengan keluarga dan lingkungan sosial.

Berdasarkan hasil penelitian mengenai bentuk keterpurukan penyandang disabilitas pada waktu masa kecil dan remaja di Kota Makassar, maka dapat dijabarkan bahwa penyandang 
disabilitas baik penyandang disabilitas rungu, disabilitas daksa, disabilitas wicara, disabilitas netra maupun disabilitas ganda, pada umumnya memiliki bentuk keterpurukan yang hampir sama. Penyandang disabilitas mengalami ejekan, hinaan dan diskriminasi lainnya terkait disabilitas yang mereka alami, bahkan beberapa penyandang disabilitas mengalami kekerasan fisik di masa kanak-kanaknya.

Ejekan, hinaan dan gangguan yang sering penyandang disabilitas dapatkan di masa kecilnya membuat mereka lebih banyak menghabiskan masa kecilnya di dalam rumah, yang mengakibatkan mereka kurang bergaul dan menikmati masa kanak-kanak layaknya anak normal pada umumnya. Bagi bu Ramlah selaku penyandang disabilitas rungu, selain gangguan dan ejekan dari teman seusianya dahulu, beliau juga mengalami perbedaan perlakuan atau diskriminasi dalam bergaul sehingga beliau lebih memilih berdiam di dalam rumah. Informan penyandang disabilitas daksa juga mengalami perbedaan atau diskriminasi bukan hanya dari teman bergaul tapi dari lingkungan sekolah semasa kecil. Beliau mengungkapkan bahwa dirinya sewaktu SD menjadi pemimpin upacara tetapi setelah gurunya mengetahui bahwa dirinya mengalami kecacatan di anggota tubuhnya beliau langsung digantikan menjadi pemimpin upacara oleh temannya yang normal atau tidak memiliki keterbatasan.

Rasa minder dan tidak percaya diri juga selalu ada pada penyandang disabilitas. Susahnya penyandang disabilitas dimasa kecil mendapatkan teman bergaul yang pas atau cocok membuat mereka dalam bergaul memiliki rasa minder dan tidak percaya diri yang lebih ketika bergaul dengan teman-teman yang normal atau non disabilitas. Besarnya rasa tidak percaya diri penyandang disabilitas bisa mengakibatkan penyandang disabilitas tidak menerima keterbatasan yang mereka alami. Seperti yang dialami pak Syaifuddin Pulo penyandang disabilitas netra, sewaktu kecil beliau tidak menerima keterbatasan yang beliau alami, sempat mengalami keterpurukan selama berapa tahun di kampungnya, mengalami keputusasaan dengan kondisi yang dimiliki serta sempat memaki-maki Tuhan akan kecacatan yang beliau alami.

Berdasarkan hasil penelitian diketahui bahwa konsep diri penyandang disabilitas pada awal mengalami/menyadari disabilitasnya memiliki konsep diri negatif, yang terbentuk dari persepsi dari dalam diri (in self) penyandang disabilitas yang negatif dan persepsi dari luar diri (out self) juga negatif.

Selain persepsi dari dalam diri dan luar diri yang membentuk konsep diri penyandang disabilitas, pada awal menerima dan menyadari disabilitas, dari hasil wawancara dengan informan penyandang disabilitas dan informan significant other, ditemukan beberapa faktor yang mengubah konsep diri penyandang disabilitas yang awalnya memiliki konsep diri negatif menjadi lebih baik atau positif yang menumbuhkan kepercayaan diri sebelum memutuskan memenuhi kebutuhan hidup dengan berwirausaha, yaitu: (1) Motivasi dari dalam diri, (2) Motivasi dari luar diri dan pemberian penjelasan dengan cara yang baik tentang kondisi awal penyandang disabilitas dari keluarga. (3) Bersekolah baik sekolah umum maupun sekolah luar biasa. (4) Ikut rehabilitasi. (5) Aktif di perkumpulan atau komunitas sosial, baik komunitas sesama disabilitas maupun campuran dengan non disabilitas.

\section{Kompetensi Komunikasi Penyandang Disabilitas Dalam Berwirausaha}

Peneliti dalam penelitian ini menggunakan tiga indikator dalam mengukur kompetensi komunikasi seseorang, dalam hal ini penyandang disabilitas. Menurut Spitzberg \& Cupach, terdapat tiga indikator dalam mengukur kompetensi komunikasi seseorang yaitu motivasi (motivation), pengetahuan (knowledge), dan keterampilan (skill).

Motivasi (motivation) biasanya berhubungan dengan tujuan-tujuan tertentu yang ingin dicapai, seperti untuk menjalin hubungan baru, mendapatkan informasi yang diinginkan, dan lain sebagainya. Semakin individu memiliki keinginan untuk berkomunikasi secara efektif dan meninggalkan kesan yang baik terhadap orang lain, maka akan semakin tinggi motivasi individu untuk berkomunikasi.

Pengetahuan (knowledge) tentang komunikasi menurut Spitzberg \& Cupach diantaranya pengetahuan mengetahui apa yang harus diucapkan, tingkah laku seperti apa yang harus diambil dalam situasi yang berbeda, bagaimana orang lain akan menanggapi dan berperilaku, siapa yang diajak berkomunikasi, 
serta memahami isi pesan yang disampaikan. Pengetahuan ini akan bertambah seiring tingginya pendidikan dan pengalaman.

Keterampilan (Skill) meliputi tindakan nyata dari perilaku, yang merupakan kemampuan seseorang dalam mengolah perilaku yang diperlukan dalam berkomunikasi secara tepat dan efektif. Kemampuan dalam hal ini meliputi; Other-orientation yaitu tingkah laku yang menunjukkan bahwa individu tertarik dan memperhatikan orang lain, Social anxiety meliputi bagaimana kemampuan individu mengatasi kecemasan dalam berbicara dengan orang lain dan menunjukkan ketenangan dan percaya diri dalam berkomunikasi. Expressiveness mengarah pada kemampuan dalam berkomunikasi yang menunjukkan kegembiraan, semangat, serta intensitas dan variabilitas dalam perilaku komunikasi. Hal ini dapat dilihat dari penggunaan vocal yang beragam, wajah yang ekspresif, penggunaan vocabulary yang luas, serta gerak tubuh. Interaction management merupakan kemampuan untuk mengelola interaksi dalam berkomunikasi, seperti pergantian dalam berbicara serta pemberian feedback atau respon.

Berdasarkan hasil wawancara dengan penyandang disabilitas yang bergerak di dunia kewirausahaan, peneliti menyimpulkan bahwa penyandang disabilitas yang berwirausaha memiliki kompetensi komunikasi yang baik serta kemampuan komunikasi yang dimiliki memberi pengaruh baik bagi peningkatan usaha para penyandang disabilitas sehingga bisa mengaktualisasikan dirinya di dunia kerwirausahaan sampai sekarang.

Hasil yang ditemukan dari aspek penilaian dari indikator motivasi bahwa semua penyandang disabilitas memahami tujuan untuk berkomunikasi, tapi dari segi pengetahuan dan keterampilan penyandang disabilitas rungu dan wicara kurang memadai diakibatkan oleh keterbatasan atau disabilitas yang mereka alami terhubung langsung dengan organ tubuh dalam berkomunikasi, seperti mulut yang berhubungan langsung dengan komunikasi seseorang untuk berbicara dengan oral (mulut) dan telinga berhubungan langsung dengan pendengaran. Tapi dari secara keseluruhan para penyandang disabilitas kurang mengetahui bahwa apa yang telah mereka lakukan saat berkomunikasi sudah memenuhi syarat kompetensi komunikasi dalam diri seseorang.

\section{PEMBAHASAN}

Penelitian ini menunjukkan bahwa konsep diri penyandang disabilitas pada saat mengalami/merasakan keterbatasannya yang berbeda dengan orang lain pada umumnya memiliki konsep diri yang negatif yang dipengaruhi oleh 2 hal yaitu : persepsi (in self) merupakan persepsi yang dirasakan/dialami penyandang disabilitas yang berasal dari dalam diri dan persepsi (out self) merupakan persepsi yang berasal dari luar diri penyandang disabilitas.

Informan Penyandang disabilitas memiliki masa kecil yang hampir sama. Sewaktu kecil mereka semua mengalami diskriminasi berupa ejekan, hinaan, dan gangguan-gangguan lainnya terkait disabilitas yang mereka alami. Hal-hal negatif yang sering diterima penyandang disabilitas membuat mereka memandang dirinya sebagai orang yang berbeda dengan orang lainnya. Cara pandang individu terhadap dirinya akan membentuk suatu konsep tentang diri sendiri. Sebagaimana yang dikatakan oleh Calhoun \& Acocella (1990), menjelaskan bahwa konsep diri merupakan bagian diri yang mempengaruhi setiap aspek pengalaman baik itu pikiran, perasaan, persepsi dan tingkah laku individu dengan gambaran mental individu yang terdiri dari pengetahuan tentang diri sendiri, pengharapan bagi diri sendiri dan penilaian terhadap diri sendiri.

Menurut Cooley dalam teori Looking Glass Self dalam Rakhmat (2008), kita melakukannya dengan membayangkan diri kita sebagai orang lain dalam benak kita. Dalam hal ini penyandang disabilitas mempersepsi dirinya seperti apa yang yang keluarga, teman, dan orang lain yang mengenalnya pikirkan terhadapnya, baik itu persepsi fisik penyandang disabilitas, psikologis, dan interaksi sosial dari penyandang disabilitas.

Berdasarkan teori looking glass self atau cermin diri, penyandang disabilitas dalam penelitian ini seakan-akan menaruh cermin di hadapannya pertama, penyandang disabilitas disini menilai dan memandang dirinya sendiri sesuai apa yang dia lihat dalam cermin. Kedua, penyandang disabilitas bagaimana orang lain menilai, memandang dan mempersepsi dirinya 
sesuai yang dia ketahui dan yang ketiga, penyandang disabilitas memiliki gambaran atau penilaian terhadap dirinya berdasarkan apa yang dia dan orang lain anggap dan inilah yang disebut konsep diri.

Persepsi awal yang negatif yang membentuk konsep diri negatif dari penyandang disabilitas semakin lama semakin berkurang dan semakin lama semakin menerima keterbatasan yang mereka miliki. Dari hasil penelitian yang ditemukan, ada beberapa langkah-langkah atau faktor yang membuat informan penyandang disabilitas membentuk konsep diri positif atau kearah yang lebih baik sebelum memenuhi kebutuhan hidupnya secara mandiri dengan berwirausaha seperti adanya motivasi dari dalam diri, adanya motivasi dari keluarga disertai penjelasan yang baik mengenai kondisi disabilitas yang mereka alami, bersekolah baik di sekolah umum maupun sekolah luar biasa, ikut atau aktif di perkumpulan atau komunitas sosial baik itu perkumpulan sesama penyandang disabilitas maupun campuran dengan non disabilitas dan ikut rehabilitasi bagi penyandang disabilitas yang bersekolah di sekolah umum.

Konsep diri positif tersebut juga memberikan kepercayaan diri dan pengaruh yang baik kepada pribadi penyandang disabilitas terutama pada waktu memulai wirausaha. Menurut Anthony dalam Ghufron (1992), Terbentuknya kepercayaan diri pada diri seseorang diawali dengan perkembangan konsep diri yang diperoleh dari pergaulan. Dalam hal ini adalah konsep diri positif. Sedangkan menurut Lauster (1992), bahwa memiliki konsep diri yang positif merupakan salah satu karakteristik untuk menilai kepercayaan diri.

Adanya langkah-langkah atau faktor yang membuat penyandang disabilitas untuk bangkit sedikit demi sedikit meninggalkan kesedihan dan keterpurukannya, meninggalkan ketidaknyamanan dengan mengambil langkah yang positif, ini berkaitan dengan teori disonansi kognitif dari Leon Festinger. Menurut teori ini, disonansi adalah sebuah perasaan tidak nyaman yang memotivasi seseorang untuk mengambil langkah demi mengurangi ketidaknyamanan tersebut. Lebih lanjut teori ini mengemukakan bahwa Keadaan disonansi kognitif dikatakan sebagai keadaan ketidaknyamanan psikologis atau ketegangan yang memotivasi usaha-usaha untuk mencapai konsonansi. Dimana disonansi adalah perasaan ketidakseimbangan atau ketidaknyamanan, sedangkan konsonansi adalah sebutan untuk keseimbangan (West \& Turner, 2014).

Selain konsep diri yang baik, penyandang disabilitas dalam memenuhi kebutuhannya dalam berwirausaha juga harus memiliki kompetensi komunikasi yang memadai. Kita melakukan persuasi, meyakinkan, menerangkan, membangkitkan sesuatu dengan komunikasi (Unde, 2014). Kompetensi komunikasi merupakan salah satu kompetensi yang sangat berpengaruh dalam meningkatkan efektivitas komunikasi, seperti yang diungkapkan Spitzberg \& Cupach menyatakan bahwa kompetensi komunikasi merupakan kemampuan seorang individu untuk beradaptasi dan berkomunikasi secara efektif dalam segala situasi sosial sepanjang waktu (Ibrahim, 2002).

Konsep diri dan kompetensi memiliki memiliki hubungan yang saling berkaitan. Seperti yang dijelaskan dalam uraian konsep, konsep diri termasuk dalam karakteristik yang membentuk kompetensi, bersama motif, sifat, pengetahuan dan keterampilan. Kompetensi dan konsep diri juga berada pada tingkatan yang sama dalam hierari kebutuhan Abraham Maslow yaitu kebutuhan harga diri (esteem need) pada tingkatan keempat. Kaitan dan hubungan konsep diri dan kompetensi juga bisa dilihat dari penelitian relevan sebelumnya yang dijadikan rujukan pada penelitian ini yaitu penelitian dari Putri (2010), yang berjudul "hubungan antara konsep diri dengan kemampuan komunikasi interpersonal pada penyandang tuna daksa". Pada penelitian tersebut disimpulkan bahwa ada hubungan yang positif yang sangat signifikan antara konsep diri dan kemampuan komunikasi interpersonal penyandang disabilitas (tuna daksa) di kota Surakarta.

Pentingnya kompetensi komunikasi bagi setiap individu dalam menciptakan dan membangun komunikasi yang efektif juga harus dimiliki oleh penyandang disabilitas terutama dalam memenuhi kebutuhan hidupnya dalam berwirausaha. mengutarakan indikator dalam mengukur kompetensi komunikasi seseorang dilihat dari motivasi (motivation), pengetahuan (knowledge) dan keterampilan (skill) dari yang dimiliki oleh seorang (Payne, 2005). Dalam 
penelitian ini peneliti ingin mengetahui kompetensi komunikasi yang dimiliki dari penyandang disabilitas dalam berwirausaha.

Berdasarkan hasil penelitian ditemukan bahwa kompetensi komunikasi penyandang disabilitas baik dalam berwirausaha, walaupun ada beberapa yang tidak maksimal dikarenakan disabilitas yang dialami berhubungan langsung dengan organ tubuh yang berfungsi untuk berkomunikasi. Hal ini sesuai dengan teori motivasi berprestasi dari David McClelland, menurutnya kebutuhan akan prestasi atau motivasi berprestasi tampak dari usaha yang gigih untuk mencapai keberhasilan dalam segala aktivitas kehidupan (Garliah \& Fatma, 2005). Kebutuhan ini berhubungan erat dengan mengarahkan tingkah laku pada usaha mencapai prestasi tertentu.

Peneliti melihat baiknya kompetensi komunikasi penyandang disabilitas dalam berwirausaha tidak lepas dari usaha-usaha untuk mengelola konsep dirinya dengan baik, mengarahkan konsep dirinya yang dulu negatif ke arah positif dengan bangkit dari keterpurukan dan memenuhi kebutuhan hidupnya secara mandiri dan menjalankan usahanya dengan maksimal. Seperti yang diungkapkan Fernald \& Fernald (1999), mengenai teori motivasi berprestasi David McLelland bahwa konsep diri yang baik adalah salah satu faktor yang dapat mempengaruhi motivasi berprestasi seseorang. Teori motivasi berpestasi David Mclelland, menyebutkan bahwa motivasi pada dasarnya dimiliki oleh setiap orang. Motivasi disini adalah dorongan untuk bangkit dengan usaha-usaha tertentu untuk mencapai suatu tujuan atau prestasi. Pada penelitian ini penyandang disabilitas memiliki kompetensi komunikasi yang baik yang memberikan pengaruh baik pada wirausaha yang mereka lakukan sehingga membuat orang-orang pada umumnya baik disabilitas maupun non-disabilitas sulit untuk mengikutinya. Menurut peneliti, penyandang disabilitas dalam berwirausaha telah memenuhi aspek-aspek menurut Valet (Hanifah, 2005), yaitu aspek-aspek seseorang untuk mewujudkan aktualisasi dirinya .

\section{KESIMPULAN DAN SARAN}

Penyandang disabilitas dalam berwirausaha memiliki konsep diri positif yang menumbuhkan rasa kepercayaan diri pada penyandang disabilitas, walaupun awalnya memiliki konsep diri negatif pada saat mengalami dan merasakan keterbatasannya yang dipengaruhi oleh persepsi dari dalam diri (in self) dan persepsi dari luar diri penyandang disabilitas (out self). Ada beberapa faktor yang membuat konsep diri penyandang disabilitas berubah dari awalnya memiliki konsep diri negatif dan berubah menjadi konsep diri positif sebelum memulai dan menjalankan wirausaha, yaitu adanya: (1) Motivasi dari dalam diri, (2) Motivasi dari luar diri dan pemberian penjelasan dengan cara yang baik tentang kondisi awal penyandang disabilitas dari keluarga, (3) Bersekolah baik sekolah umum maupun sekolah luar biasa, (4) Ikut rehabilitasi, (5) Aktif di perkumpulan atau komunitas sosial, baik komunitas sesama disabilitas maupun campuran dengan non disabilitas. Selain itu Penyandang disabilitas dalam berwirausaha memiliki kompetensi komunikasi baik (sadar dan berkompetensi komunikasi) yang memberikan peningkatan terhadap kegiatan usaha yang mereka lakukan. Peningkatan usaha mereka semakin lama semakin menumbuhkan aktualisasi diri mereka di dunia kewirausahaan yang sulit diikuti oleh orang lain pada umunya baik sesama disabilitas maupun non-disabilitas. Kompetensi komunikasi penyandang disabilitas dilihat dari ketiga aspek, yaitu: "Motivasi", "Pengetahuan" dan "Keterampilan". Tidak maksimalnya kompetensi komunikasi terjadi pada penyandang disabilitas rungu dan wicara pada aspek pengetahuan dan keterampilan disebabkan keterbatasan atau disabilitas yang mereka alami berhubungan langsung dengan organ tubuh yang berfungsi untuk berkomunikasi.

\section{DAFTAR PUSTAKA}

Calhoun F. \& Acocella. (1990). Psikologi Tentang Penyesuaian dan Hubungan Kemanusiaan (edisi ketiga). Semarang : Ikip Semarang Press.

Fernald L.D. \& Fernald P.S. (1999). Introduction to Psychology (5th ed). India : A.I.T.B.S Publishers \& Distributor (Regd). 
Garliah L. \& Fatma K. (2005). Peran Pola Asuh Orang Tua dalam Motivasi Berprestasi. PSIKOLOGIA . Volume I. No. 1. Juni 2005. ISSN: 18580327.

Ghufron N \& Rini R. (2010). Teori-Teori Psikologi. Jogjakarta: Ar-Ruzz Media

Hanifah, N. 2005. Hubungan Dukungan Sosial dan Kecenderungan Berpikir Positif dengan Aktualisasi Diri pada Siswa-Siswi SMPLB Bagian Tuna Daksa. Skripsi. (Tidak Diterbitkan). Surakarta: Fakultas Psikologi Universitas Muhammadiyah Surakarta.

Ibrahim M.M. (2002). Hubungan Kompetensi Komunikasi Guru Dengan Peningkatan Hasil Belajar Di Madrasah Aliyah Negeri Model Makassar. Tesis Tidak Diterbitkan. Program Studi Ilmu Komunikasi, Fakultas Ilmu Sosial dan Ilmu Politik, Universitas Hasanuddin.

International Labour Organization Jakarta. (2013). Inklusi penyandang disabilitas di Indonesia. Diakses 7 Maret 2016. Available from : http://www.ilo.org/jakarta/whatwedo/publ ications /WCMS 233426 /lang-en/index.htm

Lauster. (1992). Tes kepribadian (Terjemahan D.H. Gulo). Jakarta: PT. Gramedia Bumi Aksara

Liliweri A. (2015). Komunikasi Antar-Personal. Jakarta: Kencana Prenada Media Group.

Payne H.J. (2005). "Reconceptualizing Social Skills in Organizations : Exploring the Relationship Between Communication Competence. Job performance and supervisory roles". Journal of Leadership \& Organizational Studies, Vol 11, No. 2.

Putri R.P. (2010). Hubungan Antara Konsep Diri Dengan Kemampuan Komunikasi Interpersonal Pada Penyandang Tuna Daksa. Skripsi Tidak Diterbitkan. Fakultas Psikologi, Universitas Muhammadiyah Surakarta.

Rakhmat J. (2008). Psikologi Komunikasi. Bandung : PT. Remaja Rosdakarya.
Sugiyono. (2010). Metode Penelitian Kuantitatif Kualitatif dan R\&D. Bandung : Alfabeta.

Suroso G.T. (2015). Masyarakat Ekonomi Asean (MEA) dan Perekonomian Indonesia. diakses 6 Maret 2016. Available from : http://www.bppk.kemenkeu.go.id/publikas $\mathrm{i} /$ artikel/150-artikel-keuanganumum/20545-masyarakat-ekonomi-asean$\underline{\text { mea-dan-perekonomian-Indonesia }}$

Unde A.A. (2014). Televisi dan Masyarakat Pluralistik. Jakarta : Prenada

West R. \& Turner H.L. (2014). Pengantar Teori Komunikasi:Analisis dan Aplikasi. Jakarta: Salemba Empat. 